\title{
WORK AND CAREERS: NARRATIVES FROM KNOWLEDGE WORKERS AGED 48-58
}

\author{
Karen Handley and Birgit den Outer
}

\begin{abstract}
"Hope...which is whispered from Pandora's box only after all the other plagues and sorrows had escaped, is the best and last of all things. Without it, there is only time. And time pushes at our backs like a centrifuge, forcing us outward and away, until it nudges us into oblivion."

— Ian Caldwell, The Rule of Four
\end{abstract}

\section{INTRODUCTION}

A weakness of the burgeoning policy-related literature on older workers is a tendency to treat 'older workers' as a single, homogenous group ${ }^{2}$, overlooking the influence of intersectional factors such as income, education, social background, occupation, age, and type-of-work on individual experience. Only 'gender' has attracted sustained research attention, yet other socio-demographic characteristics are likely to have effects which are just as important. To take one example, professionally-qualified accountants have very different opportunities in later life compared with car assembly workers whose activities have been tied to 'the track' and therefore lack portability. Age itself is a key variable in older worker research. The experiences, motivations and aspirations of a 50-year old are likely to be barely comparable with those of an 85-year old; the 35-year gap is almost a generational difference. This heterogeneity of older worker experiences, contexts and situations suggests that research should be more attentive to variation. This can be partly achieved by investigating sub-groups within the broader 'older worker' category. The potential advantage of doing so is a greater understanding of older workers, which may lead to more targetted policy-making. This study seeks to contribute to this broader agenda by focusing on one particular group of workers: those aged between 48-58 employed in, or studying at a higher education institution. People in this group are getting older, but are certainly not elderly, and they potentially have many years of work ahead of

\footnotetext{
${ }^{1}$ Published as: K Handley, B den Outer 'Work and careers: narratives from knowledge workers aged 48-58' in S Manfredi, L Vickers (eds) Challenges of active ageing for equality law and for the workplace. (London: Palgrave Macmillan, 2016) pp. 209-230.

${ }^{2}$ S Vickerstaff, W Loretto and P White, 'The future for older workers: opportunities and constraints' in W Loretto, S Vickerstaff and P White (eds) The Future for older workers: new perspectives. (Bristol: Polity Press, 2007) pp. $203-226$.
} 
them. In the literature and the media, they are often referred to as the 'sandwiched' generation with caring responsibilities for their offspring as well as for longer living parents.

In the next section, the chapter proposes a narrative approach to older worker research, and then introduces the research context including the 15 participants in our study. The chapter then presents the similarities in participants' narratives, as well as four variants in the types of narratives they tell (renewal; seeking progression; winding down; and reorienting 'self' away from work). Key implications are then discussed, in particular the possibility that older workers are diverting their productive capabilities away from work as they search for a meaningful narrative for their future lives.

\section{BRINGING THE 'NARRATIVE TURN' TO OLDER WORKER RESEARCH}

The narrative turn in the social sciences ${ }^{3}$ has expanded and enriched the repertoire of approaches by which we can explore older worker experiences, identities and decision-making. It is not that narratives have been 'discovered' but that the value of narrative approaches is becoming appreciated and acknowledged. Alongside conventional survey methods and statistical data, narratives offer complementary insights. By hearing others' narratives of their pasts as well as their imagined future, we can broaden our understanding of how they perceive the horizon of work-related choices they believe are feasible or appropriate for themselves. Narratives thus provide a framework for the temporal dimension of our lives, within which we ' $\mathrm{craft}^{\prime 4}$ our narrative identities. Narratives give insights about how we think, and not just what we think; the options we consider, and not just the actions we finally take.

Narratives also offer insights into socialisation processes. This is because the way individuals talk about their imagined futures reveals something of the range of cultural stories or 'scripts' they believe to be available to them. Taken together, collected narratives produce what Czarniawska calls the 'history of narratives'. As she explains: 'to understand a society or some part of society, it is important to discover its repertoire of legitimate stories and find out how it evolved' (p. 5). Narratives provide

\footnotetext{
${ }^{3}$ B Czarniawska, Narratives in Social Science Research. (London: Sage Publications, 2003)

${ }^{4}$ D Kondo, Crafting selves: Power, Gender, And Discourses Of Identity In A Japanese Workplace. (Chicago: University of Chicago Press, 1990)
} 
insights into the identity positions that people feel are available to take on (such as 'grey-haired sage'), or which they feel constrained by (such as the 'old dear'). They shine a light on how individuals construct their work 'potential', as well as how that potential might be interpreted by others. Thus, narrative methods open up the space for critical enquiries into the politics of cultural discourses about what is 'normal' behaviour as an older worker, and whether idealised identities are accessible to everyone.

\section{INSIGHTS FROM EXISTING NARRATIVE RESEARCH}

Although contemporary narrative research has tended to focus on young people's decision making ${ }^{5}$, another strand of research has investigated individuals' experiences in periods of transition. These include experiences of redundancy among senior managers over $50^{6}$, narratives of unemployment ${ }^{7}$, and research on the narrative identity of knowledge workers in times of organisational change ${ }^{8}$. A dominant theme from this work is the performative value of individuals' narrative strategies to maintain, revise and mediate their personal and social identities. For example, Mallett and Wapshott's study - of a fast-expanding and increasinglycommercial design studio - showed how workers adjusted their personal narratives in order to retain a sense of the value of their knowledge work, for example by repositioning their career as 'developing' even in the midst of troubled organisational change.

Narrative analysis is less prevalent in research with older workers. Instead - perhaps due to the influence of gerontology and labour market studies - there has been a tendency towards creating typologies of decision-making ${ }^{9}$. McNair ${ }^{10}$, for example, identified three clusters of older workers' retirement behaviour and work orientations: choosers, survivors and jugglers. In a study of UK managers aged over 50,

\footnotetext{
${ }^{5}$ e.g. J Brannen and A Nilsen, 'Young people's time perspectives: from youth to adulthood' (2002) Sociology, 36/3, 513536. M Anderson, F Bechhofer, D McCrone, L Jamieson, Y Li and R Stewart, 'Timespans and plans among young adults' (2005) Sociology, 39/1, 139-155.

${ }^{6} \mathrm{Y}$ Gabriel, D Gray and H Goregaokar, 'Temporary derailment or the end of the line? Managers coping with unemployment at 50' (2010) Organization Studies, 31/12, 1687-1712.

7 D Ezzy, Narrating unemployment. (Aldershot: Ashgate, 2001).

${ }^{8} \mathrm{O}$ Mallett and R Wapshott, 'Mediating ambiguity: narrative identity and knowledge workers' (2012) Scandinavian Journal of Management, 28, 16-26.

${ }^{9}$ This tendency is to some extent replicated in our study, which has created a typology of participants' narratives.

${ }^{10} \mathrm{~S}$ McNair, 'How different is the older labour market? Attitudes to work and retirement among older people in Britain' (2006) Social Policy \& Society, 5/4, 485-494.
} 
Bown-Wilson and Parry ${ }^{11}$ identified a typology of four career orientations: stick, switch, slow down, and strive. Interestingly, their sampling strategy was still framed by retirement, since they selected managers who were in the process of planning for that event.

This chapter seeks to contribute to the debates on older workers by addressing some of the limitations of previous studies. Firstly, to counter-balance the tendency to homogenise 'older workers', this study looked at a particular group of workers: those aged between 48-58 involved in knowledge work. Secondly, to counter the emphasis (especially in policy research) on surveys and statistical approaches, this study took a narrative approach and explored individuals' stories of their past working lives and their imagined futures. Thirdly, although involved in the knowledge economy, our participants represented a wide diversity of older workers in terms of career stage, work history, educational background, and in factors such as having co-dependents, carer responsibilities, and so on.

\section{THE FIELD RESEARCH}

The methodology was based on narrative and situational approaches, drawing on scholars such as Gabriel, Clarke, Czarniawska and Ezzy ${ }^{12}$. Participants were invited as part of an open call to staff and (mature) students at a post-1992 British university. The call invited individuals aged 48-58 who were working (or between jobs) in the knowledge sector to take part in the interview-based research to discuss their working lives and how they saw the future of work for themselves.

During interviews, we asked participants to reflect on their decisions, aspirations, hopes and fears, in order to explore not only what they did, but also what had shaped their decisions. This is because we wanted to know what discursive and cultural resources they drew on as they constructed their identities, work trajectories, and imagined futures. Interviews lasted from one to two-and-a-half hours, and all conversations were recorded and subsequently transcribed.

\footnotetext{
${ }^{11}$ D Bown-Wilson and E Parry, 'Career progression in older managers' (2013) Employee Relations, 35/3, 309-321.

${ }^{12}$ Gabriel, 2010; Czarniawska, 2003; Ezzy, 2001; A Clarke, Situational analysis: grounded theory after the postmodern turn. (Thousand Oaks: Sage, 2005).
} 
A key aspect of analysis was its iterative and dialogic nature. As collaborative researchers, we spent considerable time reading transcripts and then discussing and comparing our interpretations and impressions. Long summaries (each of about 4 pages) were then written up for each participant, combining condensed notes, interpretative memos, and illustrative quotations. The proprietary software MAXQDA was used for data management and indexing purposes. Table 1 provides sociodemographic profiles of our participants. Of the 15 participants, 12 were employed at the university, and 3 were mature students with backgrounds in the knowledge economy, taking computing or psychology degrees. Most of our participants were women. 


\begin{tabular}{|c|c|c|c|c|}
\hline $\begin{array}{l}\text { Category of } \\
\text { 'career' }\end{array}$ & \multicolumn{2}{|c|}{ Reference $^{13}$} & $\begin{array}{l}\text { Age } \\
\text { group }\end{array}$ & Current occupation \\
\hline \multirow{9}{*}{$\begin{array}{l}\text { Frequent job } \\
\text { moves }\end{array}$} & Julia & $\mathrm{F}$ & $48-51$ & Senior administration, $\mathrm{HE}$ \\
\hline & John & M & $52-55$ & Senior administration, HE \\
\hline & Jenny & $\mathrm{F}$ & $52-55$ & Senior administration, $\mathrm{HE}$ \\
\hline & Rebecca & $\mathrm{F}$ & $48-51$ & Academic \\
\hline & Maddy & $\mathrm{F}$ & $52-55$ & $\begin{array}{l}\text { F/t mature student, after career in } \\
\text { software engineering and project mgment }\end{array}$ \\
\hline & Richard & $M$ & $48-51$ & $\begin{array}{l}\mathrm{P} / \mathrm{t} \text { mature student and } \mathrm{A} / \mathrm{V} \text { technical } \\
\text { engineer }\end{array}$ \\
\hline & Nicola & $\mathrm{F}$ & $48-51$ & Academic \\
\hline & Cathy & $\mathrm{F}$ & $56-58$ & Senior administration, $\mathrm{HE}$ \\
\hline & Simon & $M$ & $52-55$ & $\mathrm{P} / \mathrm{t}$ mature student and electrical engineer \\
\hline \multirow{6}{*}{$\begin{array}{l}\text { Worked in } \\
\text { few } \\
\text { organisations }\end{array}$} & Debbie & $\mathrm{F}$ & $56-58$ & Senior administration, $\mathrm{HE}$ \\
\hline & Maria & $\mathrm{F}$ & $48-51$ & Senior administration, $\mathrm{HE}$ \\
\hline & Susan & $\mathrm{F}$ & $56-58$ & Senior management, $\mathrm{HE}$ \\
\hline & Emma & $\mathrm{F}$ & $52-55$ & Academic \\
\hline & Bronte & $\mathrm{F}$ & $48-51$ & Senior administration, $\mathrm{HE}$ \\
\hline & Sylvia & $\mathrm{F}$ & $52-55$ & Academic \\
\hline
\end{tabular}

Table 1: Demographic profile of participants

\footnotetext{
${ }^{13}$ Pseudonyms and age-ranges have been used, to protect confidentiality
} 


\section{SOME CORE SIMILARITIES IN PARTICIPANTS' NARRATIVES}

A central feature of the narratives was the complexity of the career trajectories. These were narratives of accidental career turns and serendipitous opportunities, especially in participants' early careers but also to a lesser extent in their later career paths. Nine of the 15 participants reported frequent job moves, identifying two or more careers among those jobs. Of the other six participants - those who had worked in only a few organisations - not one person began their working life in the occupation they now inhabited. A feature of the narratives was the often casual nature of early career [post-education] decisions. Most participants talked of their first jobs as accidents - 'just a place to start'; 'almost a non-decision'; 'I simply went for jobs I thought I could pull off'.

Some participants were firm in labelling their narratives as 'not a career' but [merely] a series of jobs. This raises questions about how the meaning of career is personally understood and socially constructed, and relates to reflexive issues around selfworth. In our interviews, the word jobs was used more than career, the latter being associated with progressive ladders, or scripts one could follow, or a broader sense of work which carried status because of its impact on society. There seemed a reluctance to presume a career, but also some ambivalence. Sylvia, for example, talked of moving into lecturing from accountancy, but said she did not see it as a career because she had no plans to seek promotion. She explained:

\section{I didn't think, 'Oh, I want to be Dean one day.' No. I saw it as a really interesting job that I could combine with family life.}

A core theme in these work narratives was a sense of crafting a journey. The journey involved responding to serendipitous events and circumstances, or more proactively deciding to initiate an exciting change of direction. What was rare was a sense of planning far ahead. Rather, there seemed a preference for crafting a journey that made sense in the here-and-now, referred to by Nowotny ${ }^{14}$ as the 'extended present'. Planning was resisted because it closed down the imagined space of future opportunities, the possibility and hopefulness that 'things might turn up that are

\footnotetext{
${ }^{14} \mathrm{H}$ Nowotny, Time: the modern and postmodern experience. (Cambridge: Polity Press, 1994).
} 
interesting' [Sylvia]. Improvisation, rather than planning, allowed for the crafting of one's own destiny. We can see this perhaps as a strategy of resistance to what Gullette $^{15}$ calls the 'master narrative of decline'. By avoiding a long-term plan, one avoids having to demarcate the end-point, the dead-end.

There were, of course, influences and life events which shaped how participants crafted their career journeys. Women who became mothers made the greatest adaptations, such as changing to part-time work (or withdrawing from work for limited periods), or changing jobs to increase family income. Now in their late 40s or 50 , the women who had continued to work flexibly were able to increase their hours and commitment as their children became independent, thus avoiding some of the confidence problems associated with long-term absence from the workplace. More generally, for many of our research participants, the meaning and salience of work had changed since their early entry into the workplace. Some questioned their work's value and contribution to society; some were tired of the merry-go-round of IT consultancy 'solutions' they had seen repeatedly fail; some could now see (and wanted to begin) the next steps of a career trajectory which had hitherto been 'shrouded in mystique' [Emma]. This reorientation was significant for many of our participants, and provided a critically important platform for their future as 'older workers', opening doorways or prompting re-assessment of work-life balance. From our analysis, we categorised the ways in which participants responded to this reorientation using the typology provided in Table 2 . The typology relates to the participants in our sample and so cannot be generalised beyond that, but nevertheless offers a conceptual contribution to research in the area of older workers. Before elaborating on this typology in a later section, some illustrations will be given to show how participants conceptualised work.

\section{Changing meaning of work}

Narratives are crafted in the context of cultural discourses and shared (or contested) understandings about the meaning of work. Our participants were reflecting on their working lives in the context of these discourses, and these influences can to some extent be seen in participants' assessment of where they were in their trajectories.

\footnotetext{
${ }^{15} \mathrm{M}$ Gullette, Aged by Culture. (Chicago: University of Chicago Press, 2004).
} 
One theme from our interviews was the re-assessment of the value of different types of work. Sylvia was one of several participants who had moved from teaching or the professions into Higher Education. Initially a part-time lecturer, Sylvia had extended her involvement as her children grew up, taking on programme roles as well as several innovative teaching projects. She explained that her turn towards research about four years ago was initiated because she felt she 'ought to; because of increased pressure to do research, but not because I was terribly interested'. She described how, over time, working in a University city, she had imbibed the discourse of academia and now felt she wanted to be able to say she was an academic, not just a lecturer, and she realised that that meant doing serious research and starting a doctorate. For Emma too, the route to respectability in academia was to do a doctorate, which she also saw as opening a pathway to professorship. For both participants, this reassessment of social worth initiated a renewed spur on their career paths, and brought with it immense enjoyment and excitement.

Others asked questions about the wider impact of their work. Talk of one's contribution to society was prompted by various reasons, including prolonged exposure to one sector. Maddy, with 25 years' experience in software engineering and latterly in outsource consulting, talked of her decision to start a full-time undergraduate degree in the social sciences:

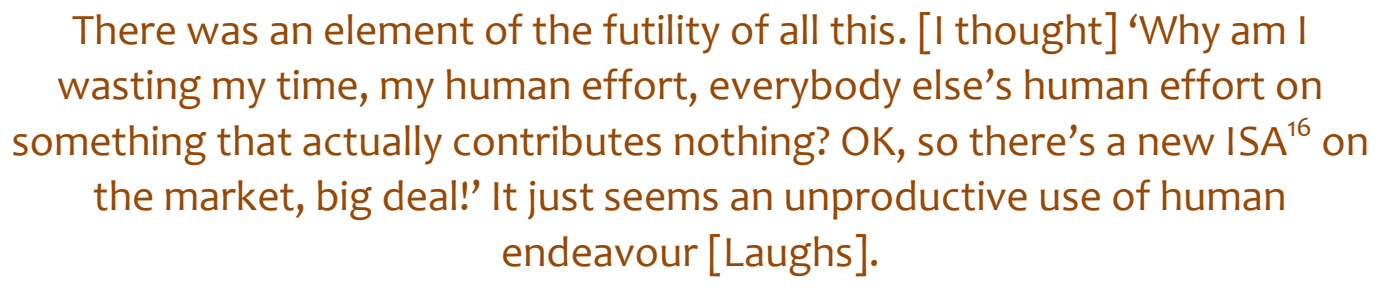

Alongside this cynicism was boredom at work. In the past, Maddy used to be excited by, and full of the possibilities of new initiatives and new technologies, but had now seen the recycling of these initiatives too many times to have any more faith in them as productive endeavours. She sorely needed a change to find renewed meaning in her working life. Richard told a similar story of becoming disillusioned with the media and advertising sector where he worked as an audio/visual/graphics engineer. He had

\footnotetext{
${ }^{16} \mathrm{An}$ ISA is a tax-exempt savings vehicle in the UK
} 
come to see the vacuousness of a consumer industry designed to seduce, sell and deceive, and could not bear any more of it. His response was to take up a part-time master's in computer engineering, a welcome return to 'hard' science.

Another theme linked to meaning and contribution concerned shifting views about how to create positive change. There was a sense of seeing a bigger picture, and taking on a more systemic perspective on social change. However, the consequences of this changed viewpoint differed. Rebecca, for example, had worked in multiple project roles in health and social care, and was increasingly frustrated by the sector's bureaucracy, and the ineffectual chaos created by perennial re-organisations. She was now taking freelance roles to achieve her desire of transforming social care. This was 'scary' financially, but gave her freedoms beyond a 'job title':

\section{I was fed up with being in a subordinate role and not being able to make enough decisions about things, and being in a structure which actually needs reorganising and you can't do anything about it. I would have more freedom as a freelance and could also use different skills with different organisations and not be just channelled in one direction.}

Richard made a similar shift, though this was more symbolic than real. His working life had always been about short-medium term contracts, but he explained that his career orientation had now changed, largely owing to his project management education in his master's. He discarded what he realised was an 'employee mentality', and felt he was now moving towards a consultancy mindset that was more professional and independent.

Whilst Richard and Rebecca epitomise the shift towards independence, and a working outside the organisation, John and Susan relished their work and influence within the organisation context. For John, work had changed its meaning because of a re-appraisal about the value of people and relationships. In his youth, as an apprenticed carpenter and painter, he liked the satisfaction of seeing the concrete product of his labours. Now, after many years as a senior manager in estates management, he talked of networks, relationships and responsibility for others' 
development. One might even say he had become 'institutionalised' in the way he spoke about his management role.

\section{CORE DIFFERENCES BETWEEN PARTICIPANTS' NARRATIVES}

Although participants shared similar tales of crafting a future trajectory of hope and possibilities, there were stark differences in their stories. Four categories were identified from our sample of 15 participants: narratives of renewal, of seeking progress, of winding down, and of reorienting 'self' away from work. Table 2 summarises participants' individual narratives. 


\begin{tabular}{|c|c|c|c|c|c|c|}
\hline $\begin{array}{l}\text { Category of } \\
\text { 'career' }\end{array}$ & Ref & & $\begin{array}{l}\text { Age } \\
\text { group }\end{array}$ & \begin{tabular}{|l|} 
Current \\
occupation
\end{tabular} & $\begin{array}{l}\text { Dominant } \\
\text { narrative }\end{array}$ & Current outlook/story \\
\hline $\begin{array}{l}\text { Frequent job } \\
\text { moves }\end{array}$ & Cathy & $\mathrm{F}$ & $56-58$ & $\begin{array}{l}\text { Senior } \\
\text { administration, } \\
\text { HE }\end{array}$ & $\begin{array}{l}\text { [Waiting for] } \\
\text { Renewal }\end{array}$ & $\begin{array}{l}\text { Despondent, feeling 'stuck' in current role and capable of } \\
\text { much more. Remains in current role because it suits family } \\
\text { constraints. Once these are lifted, she feels her life (and } \\
\text { work) can 'start again'. }\end{array}$ \\
\hline $\begin{array}{l}\text { Frequent job } \\
\text { moves }\end{array}$ & Rebecca & $\mathrm{F}$ & $48-51$ & Academic & \multirow[t]{4}{*}{ Renewal } & $\begin{array}{l}\text { Has a portfolio career and enjoys the freedom and space it } \\
\text { brings. Sense of renewal (e.g. move into education) is } \\
\text { accompanied by awareness of consolidating her sense-of- } \\
\text { purpose around 'transforming care'. Public service } \\
\text { motivation. }\end{array}$ \\
\hline $\begin{array}{l}\text { Frequent job } \\
\text { moves }\end{array}$ & Maddy & $\mathrm{F}$ & $52-55$ & $\begin{array}{l}\text { F/t mature } \\
\text { student, after } \\
\text { career in } \\
\text { software } \\
\text { engineering and } \\
\text { project mgment }\end{array}$ & & $\begin{array}{l}\text { Sees the UG degree as a 'lifebelt' opportunity which she } \\
\text { grabbed without knowing where the experience would } \\
\text { take her. Enjoying the journey. }\end{array}$ \\
\hline $\begin{array}{l}\text { Worked in } \\
\text { few } \\
\text { organisations }\end{array}$ & Emma & $\mathrm{F}$ & $52-55$ & Academic & & $\begin{array}{l}\text { Recently completed her doctorate and is full of excitement } \\
\text { about the research and development opportunities ahead. } \\
\text { Feels she has 'only just started'. }\end{array}$ \\
\hline $\begin{array}{l}\text { Worked in } \\
\text { few } \\
\text { organisations }\end{array}$ & Sylvia & $\mathrm{F}$ & $52-55$ & Academic & & $\begin{array}{l}\text { Consolidating her move into academic research, by doing } \\
\text { doctorate. Excited by prospects of this transition and the } \\
\text { impact that her research might have. }\end{array}$ \\
\hline
\end{tabular}




\begin{tabular}{|c|c|c|c|c|c|c|}
\hline $\begin{array}{l}\text { Category of } \\
\text { 'career' }\end{array}$ & Ref & & \begin{tabular}{|l|} 
Age \\
group
\end{tabular} & $\begin{array}{l}\text { Current } \\
\text { occupation }\end{array}$ & $\begin{array}{l}\text { Dominant } \\
\text { narrative }\end{array}$ & Current outlook/story \\
\hline $\begin{array}{l}\text { Frequent job } \\
\text { moves }\end{array}$ & Nicola & $F$ & $48-51$ & Academic & Renewal & $\begin{array}{l}\text { Positive about the future. Has almost completed her } \\
\text { doctorate. Looking forward to developing her teaching } \\
\text { and research, and describes her work/role as a 'new career' }\end{array}$ \\
\hline $\begin{array}{l}\text { Frequent job } \\
\text { moves }\end{array}$ & Julia & $F$ & $48-51$ & $\begin{array}{l}\text { Senior } \\
\text { administration, } \\
\text { HE }\end{array}$ & \multirow[t]{2}{*}{$\begin{array}{l}\text { Reorientation } \\
\text { from work to } \\
\text { other projects }\end{array}$} & $\begin{array}{l}\text { Questioning her tendency towards continual striving and } \\
\text { development - 'for what purpose?' Epiphanous moment } \\
\text { when passed over [for a job for which she was } \\
\text { 'exceptionally qualified'] for younger person. Coming to } \\
\text { terms with 'not going anywhere', and reorienting her } \\
\text { energies towards other projects such as writing. }\end{array}$ \\
\hline $\begin{array}{l}\text { Worked in } \\
\text { few } \\
\text { organisations }\end{array}$ & Maria & $F$ & $48-51$ & $\begin{array}{l}\text { Senior } \\
\text { administration, } \\
\mathrm{HE}\end{array}$ & & $\begin{array}{l}\text { Work is tedious. Professionalism and 'my own dignity' } \\
\text { mean she maintains high standards in her work. Enjoyment } \\
\text { is 'outside work'; and pleasure-at-work is from the } \\
\text { environment and social relationships. }\end{array}$ \\
\hline $\begin{array}{l}\text { Frequent job } \\
\text { moves }\end{array}$ & John & $M$ & $52-55$ & $\begin{array}{l}\text { Senior } \\
\text { administration, } \\
\text { HE }\end{array}$ & \multirow[t]{2}{*}{$\begin{array}{l}\text { Seeking } \\
\text { progression }\end{array}$} & $\begin{array}{l}5 \text { years since last job move, and feels it's time to step back } \\
\text { and let others through. Facing dilemma of staying put } \\
\text { (where he feels he's 'doing good'), vs. trying to progress } \\
\text { (which his 'conscious' tells him to do). }\end{array}$ \\
\hline $\begin{array}{l}\text { Frequent job } \\
\text { moves }\end{array}$ & Jenny & $F$ & $52-55$ & $\begin{array}{l}\text { Senior } \\
\text { administration, } \\
\text { HE }\end{array}$ & & $\begin{array}{l}6 \text { years since last job move. Feeling left behind as younger } \\
\text { managers pass her on the career ladder. Wants to } \\
\text { progress, but not optimistic. }\end{array}$ \\
\hline
\end{tabular}




\begin{tabular}{|l|l|l|l|l|l|l|}
\hline $\begin{array}{l}\text { Category of } \\
\text { 'career' }\end{array}$ & Ref & & $\begin{array}{l}\text { Age } \\
\text { group }\end{array}$ & $\begin{array}{l}\text { Current } \\
\text { occupation }\end{array}$ & $\begin{array}{l}\text { Dominant } \\
\text { narrative }\end{array}$ & Current outlook/story \\
\hline $\begin{array}{l}\text { Worked in } \\
\text { few } \\
\text { organisations }\end{array}$ & Susan & F & $56-58$ & $\begin{array}{l}\text { Senior } \\
\text { management, } \\
\text { HE }\end{array}$ & $\begin{array}{l}\text { Seeking } \\
\text { progression }\end{array}$ & $\begin{array}{l}\text { Enjoys current role and has opportunities to progress. } \\
\text { Feels she has potential for one more significant role, and } \\
\text { wants to make a contribution 'on a broader scale'. }\end{array}$ \\
\cline { 1 - 4 } $\begin{array}{l}\text { Frequent job } \\
\text { moves }\end{array}$ & Simon & M & $52-55$ & $\begin{array}{l}\text { P/t mature } \\
\text { student and } \\
\text { electrical } \\
\text { engineer }\end{array}$ & $\begin{array}{l}\text { Has almost completed p/t MSc in computer science. Hopes } \\
\text { his MSc credentials will enhance his employability in his } \\
\text { current sector, but is open to some renewal, e.g. IT } \\
\text { consultancy work. }\end{array}$ \\
\cline { 1 - 4 } $\begin{array}{l}\text { Worked in } \\
\text { few } \\
\text { organisations }\end{array}$ & & F & $56-58$ & $\begin{array}{l}\text { Senior } \\
\text { administration, } \\
\text { HE }\end{array}$ & $\begin{array}{l}\text { Winding } \\
\text { down }\end{array}$ & $\begin{array}{l}\text { Clearly sees her retirement horizon and wants to gradually } \\
\text { reduce hours from 60, and retire at 65. Looks forward to } \\
\text { the possibilities of interesting activities and projects in } \\
\text { retirement. Apologises that the 'pottering' sounds 'really } \\
\text { boring'. }\end{array}$ \\
\hline
\end{tabular}

Table 2: Dominant narratives in our sample, shown alongside profile of participants 


\title{
Narratives of Renewal
}

The spark that initiated a trajectory of renewal was often traceable to a reassessment of the meaning of one's work and life. As indicated earlier, reassessments of work tended to follow prolonged exposure to particular ways of working in an organisation or sector, provoking feelings of frustration, disillusionment, boredom or stagnation. For the disillusioned, 'progression' along the same path would have been anathema; they wanted to get away from the sector and start afresh in a new one, or at least (in the case of Rebecca) take a different position within the sector. For the three participants doing their doctorates, renewal was about making a serious commitment to a sector they had earlier joined as lecturers, from a professional career outside of academia, which would give the status, identity and enjoyment of doing serious research 'as academics'.

A positive sense of renewal was palpable in participants' talk. Richard spoke of divesting himself of the employee mentality, and regaining control as an independent consultant (albeit still with a client or contracting employer). Maddy called herself 'a teenager' starting afresh on her career journey. For Cathy, what sustained her tedious work was a vision that once her frail relative passed away and she no longer had caring responsibilities, she could retrain:

\begin{abstract}
It will be the end of an era, and I will literally cross into my next stage of life. I will be in control. I won't have anybody who -- if the lawn doesn't get mowed, nobody will tell me when I get in the door, I can just leave it and hope the neighbours don't notice. And then I'll be able to focus on what's important to me.
\end{abstract}

Participants in this category were excited and emboldened by new challenges and new ventures. Novelty was important, as Nicola implied when commenting on her transition into higher education: 
Whether I would be happy now if I'd done [the career move] earlier, I don't think so, because I think one of the reasons I'm quite happy and content in the roles that l've got at the moment is because it's effectively a new career that's only five years old. I haven't had time to get disillusioned with the place. [emphasis added]

She, and some others, reflected that the more one saw of an organisation, and the more one saw its 'rough edges', the less one idealised the job. It was as though this tarnished viewpoint had not yet infected those on a renewal pathway. Thus the optimism of 'renewal' challenges conventional notions of mid-life being a time of decline. These interviewees saw a future very differently, and more positively. Several commented that they had 10-15 years ahead of them, which meant that the career they were embarking on might be the longest period of time they had ever spent in the same job. This was no mere 'bridge' job before retirement.

\section{Narratives of Seeking Progression}

Progression was the intended career trajectory of four participants. The narrative here was about staying in the sector or organisation, and moving up a fairly clearlydefined ladder. This is not to say that an upwards move was inevitable. Jenny, for example, talked of wanting to progress but seeing younger managers pass her by. She sensed that the organisation wanted 'fresh blood'; a theme we return to later regarding the notion of 'potential'. Susan, in her late 50s, felt she had the capacity for 'another big job', and was already networking and engaging in extra-curricular posts in order to demonstrate (when a job opportunity arose) that she still had the energy and motivation to do an important job well. She feared that after 60 , she might be seen as 'past it'.

\section{Narratives of Winding Down}

An orientation of 'winding down' was dominant in only one of our participants. Debbie, in her mid-50s, had worked in higher education for about 15 years, and talked of a gradual reduction in her contractual hours, moving to part-time work at 60 , and retiring at 65 . Her fears, which were also articulated by another long-serving employee, was about the implications of 'going part-time'. The fears were primarily about loss: of involvement, social interaction, and having one's fingers on the pulse. 
Alongside loss might come intensification of work, according to the fear that the same job would have to be done in reduced hours. Neither participant who talked of these worries raised any concerns about loss of status. One [Bronte] ascribed this to the normalised prevalence of part-time working in the public sector. However, their responses may have been a gendered effect, and warrants further investigation.

\section{Narratives of Reorienting 'Self' away from Work}

The fourth orientation category concerns a reorientation of sense-of-self, away from work, and towards other sources of enjoyment and self-worth. It seems reasonable to ask why these participants (there were three) did not seek renewal. The main distinction is that 'renewal', as defined in our proposed typology, concerns renewalof-career. The participants in the 'reorienting' category were directing their attentions away from work, and towards other sources of interest - including self-development. Perhaps the main driver behind this category was that these participants shared a lack of intrinsic enjoyment from their current job. All three were in senior administrative roles, and perhaps did not see the sort of alternative career path which the lecturers in our sample envisioned through doing doctoral research. Their work was important, but felt tedious at times; pleasure came from the workplace environment and from relationships with people.

Participants in this category made a point of assuring the interviewer that they performed their jobs well, and were conscientious. Their sense of dignity and professionalism were maintained by ensuring that their work and the work of their teams were of a high standard. But, as one person explained: 'that doesn't mean I find it interesting to do; I do it because that's what you do'. There was perhaps some identity-positioning in the way participants distanced themselves from work, which they did not value. One person asserted that she was not defined by her job, and thought it was rather sad when others did so. She also talked of not wanting a 'higher-up job' because that would mean more stress 'and reporting', as though not necessarily more valuable than what she contributed currently. Another participant talked of an epiphanous moment in her recent past where she tried for a job for which she was 'exceptionally qualified', only to see it given to a young person without dependents because (as her job interviewer rather rashly admitted) she was likely to give less discretionary effort to the work than the younger candidate without 
children. Her reaction was to start reorienting herself towards other pursuits that were enjoyable - such as extending her involvement in local music and artistic groups. Others, too, reoriented their attentions and sense-of-self homewards, investing in activities that were not 'new' but that might have been dormant, such as writing, crafts, music and dance.

\section{POTENTIAL}

Many participants in our study reflexively considered their own potential, and talked of how they might appear to others. When asked what they felt they contributed 'as an older worker', there were common themes about having a broader perspective, being able to question strategies and not just implement them, being more sanguine and less hot-heated, having more skillful communications skills, and being more empathetic and therefore able to understand what others wanted and needed. There was also disappointment that experience and expertise built up over many years in an occupation or sector did not seem to be appreciated by others, such as those with the power to influence career progression, and those with less experienced. The ability to learn similar processes and technologies quickly - by building on pre-existing knowledge - seemed unappreciated. Cathy reflected on why this situation might persist:

I've learnt in life that people can only see as far as their experience allows
them to see; they can only understand the value of something if they
know what the value is, anything else will just not be noticed because we
all evaluate the outside world according to our standards and the highest
we can go in those standards. So if somebody has a great insight into
something, those witnessing it will only perceive if it they can understand it.

Cathy talked of how she learnt to bite her tongue rather than intervene to suggest alternative ways of doing things to her colleagues: she'd been 'pushed down too many times'. Others were more sanguine, recognising that experience can't be 'taught', but acknowledging that avoidable mistakes might be made by others. This apparent passivity - watching predictable mistakes unfold - might seem irresponsible, but interviewees seemed unsure what to do instead. There was recognition that 
organisations wanted 'fresh ideas; fresh blood', graduates who were 'malleable' and could be socialised easily. Older workers, almost by definition, could not offer that. Some talked of their growing irritation about being asked to mentor and develop others who would soon overtake them. This situation seemed more prevalent in senior administrative roles. Cathy illustrates the frustrations of this double-speak:

I'm so tired of him [manager] coming to me and saying, 'Oh, so and so wants the younger ones, l'd like you to work with her [the younger recruit], because it's an opportunity for her growth,' and I said to him, 'What about my growth?' ... It seems like there are two languages, the young get this and people are put into positions as an opportunity for growth, but with the older ones, suddenly they say, 'Well you didn't have this or that.' And so you don't go to [selection] interviews.

On the other hand, John, a senior manager already, talked of wanting to let others come in with new ideas, but perhaps because he was more positive about the likelihood that he could seek out and get a promotion. 'Potential' was seen as an attribute of the young, and if you were stuck in the same job for too long, your potential (based on prior experience and knowledge) would become invisible. There was a vicious circle of invisibility as one got older, and also a visibility of getting older. This was especially problematic for women. Rebecca pondered whether she needed to have a certain level of seniority before she could stop dyeing her hair and become grey. Maddy felt that older women are respected and valued in the workplace but only if they have a senior role, and in any case the respect would be 'for clichéd reasons' and not necessarily desirable. Cathy talked of a potential new role in the future if she could make herself invisible and only 'virtually present' so that she could hide her age whilst producing work of the quality of an 18 year old. A rather different strategy was adopted by Susan, who endeavoured to signal her continued energy and commitment by taking on more discretionary responsibilities including nonexecutive leadership roles.

The narratives show that 'potential' can be rekindled, but perhaps only in certain circumstances. It is interesting to note that the three participants embarking on or finishing their doctorates had a strongly positive sense of their own potential. This seemed linked to the possibility, in higher education, to [re] start a career with a 
doctorate. One could be an older 'early career researcher', and as such, the benefits of presumed potential were more attainable.

\section{RETIREMENT}

'Retirement' seemed remote for most participants. It was part of the temporal horizon, but not necessarily attractive because of connotations of finality. Retirement was in some ways more of a mental challenge than a practical one; and many participants were ambivalent about it.

Less than half mentioned any concerns about finances. Among those who did, none seemed to have translated this concern into a work-to-retirement plan for financial security. Even those who described themselves as largely motivated by money were unsure of their pension provision. One person worried about the further dismantling of the welfare state, implying that focused planning was fairly futile given this uncertainty. More generally, finances were 'in the background': none of the participants had yet made specific retirement plans based on financial calculations of future income and expenses. For some, their future time horizon was populated by 'pensionable age' dates. Debbie, for example, spoke of going part-time at 60 , and retiring at 65 . Age as a 'stepping off point' featured in the conversations of longserving employees, albeit with some uncertainly as to the State Pension Age that applied to their cohort. But more generally, interview questions about retirement prompted some ambivalence. Retirement was about freedom, flexibility and time.

\section{[Retirement means] being in a position financially, emotionally, to be able to say ... 'yes' or 'no' to what you wanted to do.... And it's certainly nothing about not doing things, it's all about doing what you want to do.}

\section{[Nicola]}

Retirement gave one options and opportunities, but also a restfulness that was almost mentioned in hushed tones as though inappropriate. Debbie apologised for admitting that she might actually spend time 'pottering' in the garden -'it sounds really boring'. Earlier in the conversation, she had reeled off a number of possible activities such as helping children to read, doing things in the village, talking to people in hospital, and looking after dogs. Her later admission implies that some 'identity 
work' was going on ${ }^{17}$. What seemed important was to convey (to oneself, or the interviewer) a positive sense of opportunities and options, creating a positive images of one's future 'possible self' ${ }^{18}$, presenting a horizon of possibilities rather than a cliffedge of decline and misery after work. Others said they would be 'bored at home'; the solution was 'voluntary work in the community; anything really' [Jenny], and 'charity work or whatever' [Richard], implying a sense of bits-and-pieces which was rather vague as though something had to be there to fill a possible - but unacceptable - void. A few, such as Rebecca, talked of wanting to work for as long as they could:

I think I'll just keep working at whatever I can work at for as long as I can.

I: Where do you picture yourself at $75 / 80$ ?

Well I hope by 80 I would be retired! <Laughs> But I would like to still be involved. I would probably volunteer for charities, I would probably be a trustee for something. I'd probably be running little, local things in my community, I wouldn't want to just be sitting at home.. [I'll be] taking up new hobbies and doing things which I haven't had a chance to do before. So I could see my retirement being very busy' <laughs>.

\section{CONCLUSION}

This exploratory study, grounded in the specific setting of university employment and education, has generated a number of themes with implications for the active ageing agenda, and for understanding the experiences of 'younger' older workers. Themes include: the prevalence of narratives of hope, renewal and reorientation; resistance to the 'master narrative of decline'; leakage of energies away from the workplace; and the problematic discourse of 'potential'.

In their conversations about work, life and the future, participants in our study were crafting narratives which constructed for themselves something positive; something to look forward to. Even the gloomiest story of being 'stuck' was interspersed with slivers of hope: Cathy was staunchly optimistic that her life would re-start once her caring responsibilities were completed. The narratives were hopeful, and varied. Those who saw a pathway of career renewal (e.g. becoming a research academic

\footnotetext{
${ }^{17} \mathrm{M}$ Alvesson $\mathrm{H}$ Willmott, 'Identity regulation as organizational control: producing the appropriate individual' (2002) Journal of Management Studies, 39/5, 619-644

${ }^{18}$ H Markus and P Nurius, 'Possible Selves' (1986) American Psychologist, 41, 954-969
} 
through the transitional step of doing a doctorate), or who had taken opportunities to re-educate themselves, told very different stories from those who felt stuck in a department with limited scope for job movement. The latter participants could not see a development path at work, and instead talked of taking up new pursuits outside of work; of diverting their creative energies elsewhere whilst retaining a professional commitment to performing their work well. The dominant theme across all participants was a drive to create a (future) narrative which offered opportunities to flourish, to deflect identity threats signalled by the 'master narrative of decline ${ }^{19}$, and to push back the boredom of retirement. Restfulness seemed to be nonpermissible and almost frightening in its cavernous emptiness, pushed back by the possibilities for 'bits and pieces' of other activities.

This human need to hope, dream and create an imagined future is a theme which resonates in the arts and literatures of all cultures. It is exemplified in literature such as Viktor Frankl's Man's Search for Meaning ${ }^{20}$, an account of extreme suffering and hope in the Nazi concentration camps. What our study shows is that in searching for meaning, some participants were withdrawing their energies and discretionary effort from paid work to seek a more positive sense of self elsewhere, for example in voluntary work, creative endeavours or social activities. An implication of this is the risk that the productive capability of older workers may be seeping out of the paidwork sector of the economy. Our findings point to a tension between older workers' desire for interesting development and to create a strong sense of their working self, and the positions that are culturally available or assigned to them by their organisations. This is perhaps ironic given that a legacy of the human relations movement, following Maslow and others, has been 'a continuous effort [from employers] to co-opt the individual's mental and spiritual energies in the service of profit $^{21}$. These co-opting processes seem to be focused on younger workers, neglecting the energetic potential of older workers. What our participants did not want was merely to be asked to 'look after' others who were being promoted in their place - to be unpaid (and undervalued) workplace carers. A key message from our

\footnotetext{
${ }^{19}$ Gullette, 2004; H Vough, C Bataille, S Noh and M Lee, 'Going off script: how managers make sense of the ending of their careers' (2015) Journal of Management Studies, 52/3, 414-440.

${ }^{20}$ V Frankl, Man's search for meaning: The classic tribute to hope from the Holocaust. (Reading: Rider, 2004/1946).

${ }^{21}$ A Lait, Telling tales: work, narrative and identity in a market age. (Manchester: Manchester University Press, 2012), p120.
} 
participants was that as older workers, they have much to offer. They feel capable of doing more, and are far from 'past it'. 